\title{
The role of chronic blood loss in the pathogenesis of postgastrectomy iron-deficiency anaemia
}

\author{
J. M. HOLT, M. W. L. GEAR, AND G. T. WARNER \\ From the Nuffield Department of Clinical Medicine and the Department of Surgery, Radcliffe \\ Infirmary, Oxford
}

SUMMARY The role of chronic blood loss in the pathogenesis of postgastrectomy irondeficiency anaemia was assessed by measurements of blood loss over periods of up to three months, using a whole-body counter and ${ }^{59} \mathrm{Fe}$. Eleven patients were investigated and eight of these were selected because of a history of iron-deficiency anaemia. Six were shown to be, losing blood abnormally, five at a rate of over $150 \mathrm{ml}$ per month. None of the three patients without a history of anaemia lost more than $60 \mathrm{ml}$ per month. At gastroscopy contact bleeding from the mucosa of the gastric remnant was observed in four of the six patients losing blood. The results indicate that in some patients chronic blood loss plays an important role in the pathogenesis of postgastrectomy iron-deficiency anaemia.

There has been controversy over the part played by chronic gastrointestinal blood loss in the pathogenesis of postgastrectomy iron-deficiency anaemia. Witts (1966) suggested that intermittent bleeding associated with gastritis of the gastric remnant might be an important factor, and Kimber, Patterson, and Weintraub (1967), who measured the faecal loss of infused ${ }^{51} \mathrm{Cr}$-labelled red cells in a group of eight patients, demonstrated losses of up to $6.5 \mathrm{ml} /$ day. However, in a more recent paper Baird, St. John, and Nasser (1970), who studied a larger group by the same method, failed to confirm this work and concluded that occult gastrointestinal blood loss is not important in the pathogenesis of postgastrectomy anaemia. This paper describes a study designed to examine this possibility further using ${ }^{59} \mathrm{Fe}$ and the Oxford whole-body counter (Warner and Oliver, 1966).

\section{Patients and Methods}

Eleven patients, nine males and two postmenopausal females, who had undergone partial gastrectomy five to 24 years previously for peptic ulcer were investigated. Eight were selected beReceived for publication 24 March 1970. cause of a history of iron-deficiency anaemia; three of these had received treatment. At the beginning of the study four of the patients had haemoglobin levels of less than $10 \mathrm{~g} / 100 \mathrm{ml}$ (Table). No abnormality other than partial gastrectomy could be found on radiological investigation of the gastrointestinal tract.

Chronic blood loss during intervals of up to three months was calculated from measurements of the rate of loss in whole-body activity following the intravenous injection of $4 \mu \mathrm{Ci}{ }^{59} \mathrm{Fe}$ using a whole-body counter, and the blood volume. Details of the method have been described before (Callender, Witts, Warner, and Oliver, 1966; Holt, Mayet, Warner, and Callender, 1967). The blood volume was estimated from knowledge of the patients' heights and weights (Nadler, Hidalgo, and Bloch, 1962). In addition, the rate of loss of activity was measured in nine control subjects. These comprised six normal male volunteers, two posthysterectomy and one postmenopausal women who were otherwise normal. Their ages ranged between 26 and 64 years.

As a preliminary investigation, two tests of iron absorption were carried out. In one test ferrous iron absorption was measured from $5 \mathrm{mg}$ ferrous sulphate and $50 \mathrm{mg}$ ascorbic acid 
labelled with $2-3 \mu \mathrm{Ci}{ }^{59} \mathrm{Fe}$. In the second test absorption of ferric iron was measured using $5 \mathrm{mg}{ }^{50} \mathrm{Fe}$ ferric chloride. The doses were given in solution after a two-hour fast. A proportion of food iron occurs as ferric iron and it was thought that the use of ferric chloride might give some assessment of the patients' ability to absorb food iron.

In seven patients the gastric remnant and stoma were examined gastroscopically using an Olympus gastroscope with facilities for photography, exfoliative cytology, and biopsy under direct vision (Williams, Truelove, Gear, Massarella, and Fitzgerald, 1968). In some patients biopsies from two sites were taken. The friability of the gastric mucosa and its tendency to bleed on contact was assessed by stroking the mucosa firmly with the cytology brush under direct vision.

In addition the results from studies of two further patients are presented. One of these (case 12) had undergone vagotomy and pyloroplasty and the second (case 13) had been treated by gastroenterostomy and vagotomy (Table). ment of blood loss and iron absorption are summarized in the Table.

\section{BLOOD LOSS}

The rate of loss of whole-body activity following the intravenous injection of ${ }^{59} \mathrm{Fe}$ is shown in the Figure where graphs of the activity in eight patients with a history of anaemia (cases 1-8), are compared with graphs of activity in three patients with no history of anaemia (cases 9,10 , and 11). The range of loss in the nine controls is shown for comparison. Six of the patients with a history of anaemia lost activity at a rate greater than normal. The calculated rate of blood loss in the six patients ranged between 90 and $230 \mathrm{ml}$ per month and three patients (cases 1,3 , and 5) lost at a rate of $200 \mathrm{ml}$ or more per month (Table).

The patient who had previously undergone gastroenterostomy with vagotomy (case 13) also lost blood abnormally, but no significant loss was detected in the patient treated by vagotomy and pyloroplasty (case 12).

IRON ABSORPTION

Seven of the 10 patients in whom tests of iron absorption were carried out were iron deficient (serum iron less than $70 \mu \mathrm{g}$ per $100 \mathrm{ml}$ ) at the time of study. In only one patient (case 5)
The clinical details of the patients and measure-

\section{Results}

\begin{tabular}{|c|c|c|c|c|c|c|c|c|c|}
\hline $\begin{array}{l}\text { Case } \\
\text { No. }\end{array}$ & Age $(y r)$ & Sex & Type of Operation & $\begin{array}{l}\text { Interval } \\
\text { since } \\
\text { Operation } \\
(y r)\end{array}$ & Previous Symptoms & $\begin{array}{l}\text { Haemo- } \\
\text { globin } \\
(\mathrm{g} / 100 \mathrm{ml})\end{array}$ & $\begin{array}{l}\text { MCHC } \\
(\%)\end{array}$ & $\begin{array}{l}\text { Serum } \\
\text { Iron } \\
(\mu / 100 \mathrm{ml})\end{array}$ & Gastroscopic Findings \\
\hline 1 & 62 & $\mathbf{M}$ & Polya for duodenal ulcer & 15 & - & $7 \cdot 7$ & 28 & 34 & \multirow{2}{*}{$\begin{array}{l}\text { Marked hyperaemia } \\
\text { with contact bleeding } \\
\text { Marked gastritis } \\
\text { throughout remnant }\end{array}$} \\
\hline 2 & 56 & $\mathbf{M}$ & $\begin{array}{l}\text { Billroth I for gastric } \\
\text { ulcer }\end{array}$ & 9 & $\begin{array}{l}\text { Severe iron-deficiency anaemia } \\
\text { (Hb } 4 \mathrm{~g} / 100 \mathrm{ml}) 6 \text { years } \\
\text { previously }\end{array}$ & $6 \cdot 4$ & 25 & 14 & \\
\hline 3 & 49 & $\mathbf{M}$ & $\begin{array}{l}\text { Polya for acute gastric } \\
\text { ulcer }\end{array}$ & 18 & - & 6.9 & 26 & 20 & \multirow{2}{*}{$\begin{array}{l}\text { Marked superficial } \\
\text { gastritis with contact } \\
\text { bleeding } \\
\text { Marked gastritis with } \\
\text { contact bleeding }\end{array}$} \\
\hline 4 & 67 & $\mathbf{M}$ & Polya for duodenal ulcer & 23 & $\begin{array}{l}\text { Mild iron-deficiency anaemia } \\
\text { (Hb } 10 \mathrm{~g} / 100 \mathrm{ml}) 5 \text { years } \\
\text { previously }\end{array}$ & 12.9 & 30 & 66 & \\
\hline 5 & 52 & $\mathbf{F}$ & Polya for duodenal ulcer & 5 & - & $8 \cdot 7$ & 30 & 22 & \multirow{2}{*}{$\begin{array}{l}\text { Peristomal gastritis with } \\
\text { contact bleeding } \\
\text { Not done }\end{array}$} \\
\hline 6 & 34 & $\mathbf{M}$ & Polya for duodenal ulcer & 11 & $\begin{array}{l}\text { Mild iron-deficiency anaemia } \\
\text { (Hb } 10 \mathrm{~g} / 100 \mathrm{ml}) 12 \text { months } \\
\text { previously }\end{array}$ & $13 \cdot 2$ & 33 & 24 & \\
\hline 7 & 68 & $\mathbf{M}$ & Polya for duodenal ulcer & 24 & $\begin{array}{l}\text { Mild iron-deficiency anaemia } \\
\text { (Hb } 10 \mathrm{~g} / 100 \mathrm{ml}) 15 \text { years } \\
\text { previously }\end{array}$ & $13 \cdot 2$ & 36 & 116 & Not done \\
\hline 8 & 69 & $\mathbf{F}$ & Billroth I for gastric ulcer & 13 & $\begin{array}{l}\text { Gastrointestinal haemorrhage } \\
\text { (Hb 8g/100ml) } 6 \text { months } \\
\text { previously }\end{array}$ & $14 \cdot 7$ & 33 & 103 & $\begin{array}{l}\text { Marked gastritis } \\
\text { throughout }\end{array}$ \\
\hline $\begin{array}{r}9 \\
10 \\
11\end{array}$ & $\begin{array}{l}60 \\
61 \\
56\end{array}$ & $\begin{array}{l}\mathbf{M} \\
\mathbf{M} \\
\mathbf{M}\end{array}$ & $\begin{array}{l}\text { Polya for duodenal ulcer } \\
\text { Billroth I for gastric ulcer } \\
\text { Polya for duodenal ulcer }\end{array}$ & $\begin{array}{r}8 \\
20 \\
13\end{array}$ & 二 & $\begin{array}{l}13 \cdot 5 \\
17 \cdot 2 \\
13 \cdot 7\end{array}$ & $\begin{array}{l}34 \\
37 \\
33\end{array}$ & $\begin{array}{r}54 \\
130 \\
45\end{array}$ & $\begin{array}{l}\text { Mild-moderate gastritis } \\
\text { Not done } \\
\text { Not done }\end{array}$ \\
\hline 12 & 61 & $\mathbf{M}$ & $\begin{array}{l}\text { Vagotomy and pyloro- } \\
\text { plasty for duodenal ulcer }\end{array}$ & 6 & $\begin{array}{l}\text { Mild iron-deficiency anaemia } \\
\text { (Hb 11g/100ml) } 4 \text { months } \\
\text { previously }\end{array}$ & $16 \cdot 0$ & 36 & 74 & \multirow{2}{*}{$\begin{array}{l}\text { Marked superficial } \\
\text { gastritis with contact } \\
\text { bleeding in prepyloric } \\
\text { area } \\
\text { Peristomal gastritis }\end{array}$} \\
\hline 13 & 56 & $\mathbf{M}$ & $\begin{array}{l}\text { Gastroenterostomy and } \\
\text { vagotomy for duodenal } \\
\text { ulcer }\end{array}$ & 20 & - & 6.7 & 29 & 11 & \\
\hline
\end{tabular}


was a compensatory increase in absorption of ferric chloride demonstrated, suggesting that in six patients the absorption of food iron would be poor and fail to increase in response to iron deficiency. Absorption of ferrous iron was not impaired and all the iron-deficient subjects absorbed more than $20 \%$ of the administered dose.

\section{GASTRITIS}

The gastroscopic findings in seven patients and the histological appearances at biopsy in six are described in the Table. On direct examination the mucosa appeared abnormal in all the patients examined, and in four the mucosa bled freely after it had been stroked firmly with the cytology brush. Superficial gastritis or atrophic gastritis was found on gastric biopsy in five patients examined histologically; the histological appearance in one patient was normal. In no case was a stomal ulcer found.

\section{Discussion}

These results indicate that chronic blood loss does occur in some patients following partial gastrectomy and support the findings of Kimber et al (1967) who suggested that blood loss plays an important role in the development of postgastrectomy iron-deficiency anaemia. Although the magnitude of loss described here, in the order of $150-200 \mathrm{ml}$ per month, is not great compared with monthly losses of over $500 \mathrm{ml}$ found in some patients with hiatus hernia (Holt, Mayet, Warner, Callender, and Gunning, 1968) or $400 \mathrm{ml}$ in some patients with inactive ulcerative colitis (Stack, Smith, Jones, and Fletcher, 1969), its significance is greater because of defective absorption of food iron. In normal subjects absorption of food iron increases in response to iron deficiency but such an adjustment does not occur in the postgastrectomy state (Baird and Wilson, 1959; Turnberg, 1966). The 'poor absorption of ferric iron in six of the seven iron-deficient patients described here supports this view.

Baird et al (1970), who measured the faecal loss of infused ${ }^{51} \mathrm{Cr}$-labelled red cells, found no important blood loss in a group of 19 patients in whom no cause for anaemia other than the postgastrectomy state could be found. Nor, apart from one case, was there any greater tendency to gastrointestinal bleeding during the administration of aspirin by mouth compared with a group of control patients treated in the same way. They therefore concluded that occult gastrointestinal blood loss is not an important cause of postgastrectomy iron-deficiency anaemia. The

\begin{tabular}{|c|c|c|c|c|c|c|c|}
\hline \multirow{2}{*}{$\begin{array}{l}\text { Site of Gastric } \\
\text { Biopsy }\end{array}$} & \multirow[t]{2}{*}{ Histology } & \multicolumn{2}{|c|}{ Iron Absorption (\%) } & \multicolumn{2}{|c|}{ Calculated Blood Loss $(\mathrm{ml})$} & \multirow{2}{*}{$\begin{array}{l}\text { Interval } \\
\text { of Study (wk) }\end{array}$} & \multirow{2}{*}{$\begin{array}{l}\text { Percentage } \\
\text { Retention }{ }^{50} \mathrm{Fe} \text { at } \\
\text { End of Study }\end{array}$} \\
\hline & & Ferrous Iron & Ferric Iron & Per Month & Total & & \\
\hline \multirow{2}{*}{$\begin{array}{l}\text { Fundus } \\
\text { Peristomal area } \\
\text { Peristomal area }\end{array}$} & $\begin{array}{l}\text { Atrophic gastritis } \\
\text { Atrophic gastritis }\end{array}$ & 22 & 2 & 230 & 800 & 14 & 83 \\
\hline & $\begin{array}{l}\text { Focal atrophic and superficial } \\
\text { gastritis }\end{array}$ & 20 & $\mathbf{0}$ & 150 & 450 & 12 & 90 \\
\hline $\begin{array}{l}\text { Fundus } \\
\text { Peristomal area }\end{array}$ & $\begin{array}{l}\text { Normal } \\
\text { Gastric atrophy }\end{array}$ & 30 & 5 & 220 & 720 & 13 & 87 \\
\hline $\begin{array}{l}\text { Fundus } \\
\text { Peristomal area }\end{array}$ & $\begin{array}{l}\text { Normal } \\
\text { Superficial gastritis }\end{array}$ & 23 & $\mathbf{0}$ & 190 & 700 & 15 & 82 \\
\hline \multirow[t]{3}{*}{$\begin{array}{l}\text { Fundus } \\
\text { Peristomal area }\end{array}$} & $\begin{array}{l}\text { Normal } \\
\text { Normal }\end{array}$ & 53 & 17 & 200 & 650 & 13 & 85 \\
\hline & & 23 & $\mathbf{0}$ & 20 & 40 & 10 & 99 \\
\hline & & 6 & 2 & 60 & 150 & 10 & 97 \\
\hline \multirow[t]{2}{*}{$\begin{array}{l}\text { Fundus } \\
\text { Peristomal area }\end{array}$} & $\begin{array}{l}\text { Chronic superficial gastritis } \\
\text { Chronic superficial gastritis }\end{array}$ & 2 & 1 & 90 & 300 & 13 & 90 \\
\hline & & $\begin{array}{l}15 \\
21\end{array}$ & $\begin{array}{l}\mathbf{0} \\
\mathbf{3}\end{array}$ & $\begin{array}{r}20 \\
30 \\
0\end{array}$ & $\begin{array}{r}60 \\
100 \\
0\end{array}$ & $\begin{array}{l}13 \\
14 \\
14\end{array}$ & $\begin{array}{l}99 \\
98 \\
96\end{array}$ \\
\hline $\begin{array}{l}\text { Fundus } \\
\text { Gastric antrum }\end{array}$ & $\begin{array}{l}\text { Severe atrophic gastritis } \\
\text { Severe atrophic gastritis }\end{array}$ & 12 & 9 & 0 & 0 & 11 & 100 \\
\hline $\begin{array}{l}\text { Fundus } \\
\text { Peristomal area }\end{array}$ & $\begin{array}{l}\text { Chronic superficial gastritis } \\
\text { Chronic superficial gastritis }\end{array}$ & \multicolumn{2}{|l|}{ Not done } & 300 & 750 & 10 & 83 \\
\hline
\end{tabular}




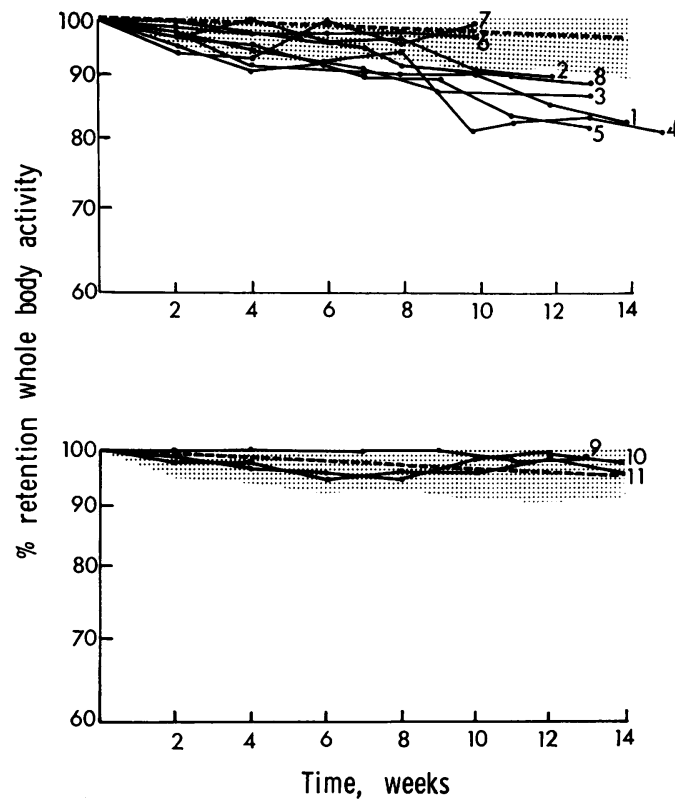

Figure Percentage retention of the administered dose plotted against time in weeks. The graphs from eight patients with a history of iron-deficiency anaemia (cases 1 to 8: upper diagram) are contrasted with graphs from three patients (cases 9, 10, and 11: lower diagram) with no history of anaemia. The mean loss in nine controls is indicated by the broken line and the range of losses is enclosed in the shaded area.

present study and that reported by Baird et al (1970) differ in a number of ways. First, our patients were investigated whilst attending as outpatients and it is possible that the dietary habits of patients living at home differ from those of patients in hospital, being more likely to lead to mucosal damage and consequent haemorrhage. Secondly, our studies were carried out over periods of time of up to 15 weeks so that there was a greater chance of detecting intermittent loss. The intermittent nature of the blood loss in some patients is illustrated in the Figure. For example, in case 5 most of the fall in whole-body activity occurred between weeks 8 and 10. One of the patients reported by Kimber et al (1967) lost blood only episodically.

Most of our patients, like those reported by Kimber et al, were studied while still iron deficient. In contrast, Baird et al (1970) corrected the iron deficiency of their patients before measurements of blood loss were made. It is therefore possible that the iron-deficient state might predispose to mucosal haemorrhage.

From our observations at gastroscopy, it seems likely that blood loss is associated with increased friability of the mucosa in the peri- stomal area of the gastric remnant and a greater tendency to bleed from it following trauma. However, the degree of gastritis at biopsy varied widely, and in one patient (case 5) shown to be losing blood biopsies both from the fundus and stomal areas were normal, yet the mucosa near the stoma bled readily on contact.

A number of factors may collectively contri- $\frac{\overline{\bar{D}}}{\bar{D}}$ bute to the development of iron-deficiency anae- $\varrho$ mia following partial gastrectomy. First, the ${ }^{\Perp}$ patient may have been iron deficient at the time $\overrightarrow{0}$ of operation because of previous gastrointestinal haemorrhage. Second, appetite may be poor fol- $\vec{\omega}$ lowing partial gastrectomy and lead to a $\operatorname{diet} \stackrel{\varrho}{\varrho}$ deficient in iron (Baird, Blackburn, and Wilson, $\subsetneq$ 1959). Third, food iron may be poorly absorbed, and fourth the patient may bleed occultly from $\vec{\circ}$ the gastric remnant even 15 or 20 years after $\infty$ operation.

We wish to thank Miss Marjorie Alcock for her careful technical assistance and $\mathrm{Dr}$ Sheila ${ }_{\mathbb{D}}$ Callender for her advice. The work was supported in part by a grant from the Medical $\bullet$ Research Council.

\section{References}

Baird, I. McL., Blackburn, E. K., and Wilson, G. M. (1959). The pathogenesis of anaemia after partial gastrectomy: 1. Development of anaemia in relation to time after opera- $\overline{\mathrm{O}}$ tion, blood loss and diet. Quart. J. Med., 28, 21-34.

Baird, I. McL., St. John, D. J. B., and Nasser, S. S. (1970) Role of occult blood loss in anaemia after partial gastrectomy. Gut, 11, 55-61.

Baird, I. McL., and Wilson, G. M. (1959). The pathogenesis of anaemia after partial gastrectomy. 2. Iron absorption after partial gastrectomy. Quart. J. Med., 28, 35-41.

Callendar, S. T., Witts, L. J., Warner, G. T., and Oliver, R. (1966). The use of a simple whole-body counter for haematological investigations. Brit. J. Haematol., 12, 276-282.

Holt, J. M., Mayet, F. G. H., Warner, G. T., and Callender, S. T. 윽 (1967). Measurement of blood loss by means of a wholebody counter. Brit. med. J., 4, 86-88.

Holt, J. M., Mayet, F. G. H., Warner, G. T., Callender, S. T., and Gunning, A. J. (1968). Iron absorption and blood loss in patients with hiatus hernia. Brit. med. J., 3, 22-25.

Kimber, C., Patterson, J. F., and Weintraub, L. R. (1967). The pathogenesis of iron deficiency anaemia following partial $\mathrm{N}$ gastrectomy. J. Amer. med. Ass., 202, 935-938.

Nadler, S. B., Hidalgo, J. U., and Bloch, T. (1962). Prediction of N blood volume in normal human adults. Surgery, 51, $\mathrm{W}$
224-232.

Stack, B. H. R., Smith, T., Hywel Jones, J. H. O., and Fletcher, J. (1969). Measurements of blood and iron loss in colitis with a whole-body counter. Gut, 10, 769-773.

Turnberg, L. A. (1966). The absorption of iron after partial gastrectomy. Quart. J. Med., 35, 107-118.

Warner, G. T., and Oliver, R. (1966). A whole-body counter for clinical measurements utilising the 'Shadow-Shield' technique. Phys, in Med. Biol., 11, 83-94.

Williams, D. G., Truelove, S. C., Gear, M.W. L., Massarella, G. R., $\overparen{\mathbb{D}}$ and Fitzgerald, N. W.(1968). Gastroscopy with biopsy and $\frac{\rho}{1}$ cytological sampling under direct vision. Brit. med. J., \&

Witts, L. J. (1966). The Stomach and Anaemia. Athlone Press, London. 